\title{
Yellow Fever and Traveling Athletes: Is Competing in Brazil Safe?
}

\author{
by \\ Rodrigo Luiz Vancini ${ }^{1}$, Marília Santos Andrade², \\ Cássia Regina Vancini-Campanharo ${ }^{3}$, Claudio Andre Barbosa de Lira ${ }^{4}$
}

\section{Dear Editor,}

It is acceptable to assume that the sport events globalization and increased mobility of elite athletes to endemic regions of infectious and viral diseases pose a risk to athletes and travelers. The risk of infectious diseases can be even higher in elite athletes due to their intense travel routine (Gärtner and Meyer, 2014) added to the exposure to different types of the environment where these athletes train (Turbeville et al., 2006).

Consequences of yellow fever infection could be serious: physical performance and health status not only can be compromised (Gärtner and Meyer, 2014), but also the athletes life can sometimes be at risk. For this reason we would like to draw attention to the risk of yellow fever in Brazil.

According to the World Health Organization (WHO, 2017a), a few of the most developed and populated Brazilian states (i.e. Minas Gerais, São Paulo, Bahia, Espírito Santo, and Rio de Janeiro) might be included in the considered endemic areas of yellow fever. Hence athletes, tourists, and spectators of sport events that travel to Brazil must be aware of such a problem and be informed about recommendations, health prevention plans, and campaigns.

Yellow fever is caused by a flavivirus, which is transmitted by an infected Aedes aegypti and Haemogogus mosquitoes. After the contagion, there is an incubation period of 3 to 6 days. The infection can occur in two phases with the following signs and symptoms (WHO, 2017b):

- First (acute): fever, muscle pain, headache, shivers, appetite loss, nausea, and vomiting. In this case, most people get better after 3 to 4 days;

- Second (15\% of the cases, more toxic phase, fast progression, and approximately 24 hours of remission): high fever, multiple physiological systems affected, jaundice, abdominal pain, vomiting, bleeding mouth, nose and eyes, presence of blood in the vomit and feces, and kidney function deterioration. People who enter this phase (50\%) may die within 10 to 14 days.

1 - Centro de Educação Física e Desportos (CEFD), Universidade Federal do Espírito Santo (UFES), Espírito Santo (ES), Brasil; CEFD/UFES, Campus Universitário: Av. Fernando Ferrari, 514, Goiabeiras, Vitória (ES), CEP: 29075810, Brazil.

2 - Departamento de Fisiologia, Universidade Federal de Säo Paulo (UNIFESP), São Paulo (SP), Brasil; Departamento de Fisiologia/UNIFESP: Rua Botucatu, 862, 5ํoandar, Ed. Ciências Biomédicas, Vila Clementino, São Paulo (SP), CEP: 04023-900, Brazil.

3 - Escola Paulista de Enfermagem, Universidade Federal de São Paulo (UNIFESP), São Paulo (SP), Brasil; Escola Paulista de Enfermagem - UNIFESP: Rua Napoleão de Barros, 754, 2ª andar, São Paulo (SP), CEP: 04024-002, Brazil.

4 - Setor de Fisiologia Humana e do Exercício, Faculdade de Educação Física e Dança, Universidade Federal de Goiás (UFG), Goiânia (GO), Brasil; Faculdade de Educação Física e Dança - UFG: Avenida Esperança s/n, Campus Samambaia, Goiânia (GO), CEP: 74690-900, Brasil. 
There are three types of transmission:

- Sylvatic (or jungle) - in tropical regions: the disease occurs in monkeys that pass the virus to mosquitoes. The infected mosquitoes bite humans who enter the forest;

- Intermediate - common in some parts of Africa: semi-domestic mosquitoes infect monkeys and humans. Increased contact between people and infected mosquitoes leads to transmission;

- Urban - epidemics in populated areas: infected mosquitoes transmit the virus from person to person (WHO, 2017b).

The yellow fever diagnosis - normally obtained through blood tests (for the detection of antibodies) is difficult in the early stages because it can be confused with other conditions such as poisoning and hemorrhagic fevers (e.g.: Zika and Dengue).

Although there is no specific treatment for yellow fever, the disease can be prevented with vaccination (single dose provides life-long immunity) and mosquito control (eliminating sites of reproduction, killing adult mosquitoes and larvae with insecticides applied to places with high densities of mosquitoes, and encouraging community involvement in cleaning household drains and covering water containers) (WHO, 2017b). Preventive strategies to avoid contact with mosquitoes such as air-conditioned accommodation with screened windows and doors, insect repellents, and protective clothing can be quite effective (Harley and Viennet, 2014; Ross, 2016) and therefore recommendable. Despite the lack of data on the matter we hypothesize that reported symptoms of yellow fever may affect sports performance for instance due to muscle impairment as demonstrated for Dengue and Zika infections (Brasil et al., 2016; Kalita et al., 2012; Misra et al., 2012).

Considering how easy athletes and people can travel nowadays the promotion of preventive strategies and dissemination of accurate information about yellow fever are definitely necessary to help prevent infections among athletes if they decide to compete in a country with endemic areas such as Brazil.

\section{References}

Brasil P, Calvet GA, Siqueira AM, Wakimoto M, de Sequeira PC, Nobre A, Quintana Mde S, Mendonça MC, Lupi O, de Souza RV, Romero C, Zogbi H, Bressan Cda S, Alves SS, Lourenço-de-Oliveira R, Nogueira RM, Carvalho MS, de Filippis AM, Jaenisch T. Zika Virus Outbreak in Rio de Janeiro, Brazil: Clinical Characterization, Epidemiological and Virological Aspects. PLoS Negl Trop Dis, 2016; 10: e0004636

Gärtner BC, Meyer T. Vaccination in elite athletes. Sports Med, 2014; 44: 1361-1376

Harley D, Viennet E. Football fans and fevers: dengue and the World Cup in Brazil. Lancet Infect Dis, 2014; 14: 543-544

Kalita J, Misra UK, Maurya PK, Shankar SK, Mahadevan A. Quantitative electromyography in dengueassociated muscle dysfunction. J Clin Neurophysiol, 2012; 29: 468-471

Misra UK, Kalita J, Maurya PK, Kumar P, Shankar SK, Mahadevan A. Dengue-associated transient muscle dysfunction: clinical, electromyography and histopathological changes. Infection, 2012; 40: 125-130

Ross J. What you need to know about Zika virus, 2016. Available at: http://www.health.harvard.edu/blog/what-you-need-to-know-about-zika-virus-201602019114; accessed on 03.03.2016

Turbeville SD, Cowan LD, Greenfield RA. Infectious disease outbreaks in competitive sports: a review of the literature. Am J Sports Med, 2006; 34: 1860-1865

World Health Organization (WHO). Yellow fever - Brazil, 2017a. Available at: http://www.who.int/csr/don/27-january-2017-yellow-fever-brazil/en/; accessed on 03.05.2017

World Health Organization (WHO). Yellow fever, 2017b. Available at: http://www.who.int/csr/disease/yellowfev/en/; accessed on 03.05.2017

\section{Corresponding author:}

Claudio Andre Barbosa de Lira

Universidade Federal de Goiás, Faculdade de Educação Física e Dança - Universidade Federal de Goiás; Avenida Esperança s/n, Campus Samambaia, Goiânia (GO), CEP: 74690-900, Brazil

Fone: +55-62-3521-1141; E-mail: andre.claudio@gmail.com 